\title{
日本醫科大學雜誌
}

第 7 卷、第 12 號 炤和 11 年12月15日郋行

\section{殘餘䇪素, 研究}

第1 篇 血中 2-3 /合窒素物質量二及ボス冬眠/影響

日本醫科大學內科學敉空（指溥 行德教授）

醫學士鈴・木弘治

\section{(1) 緒 言}

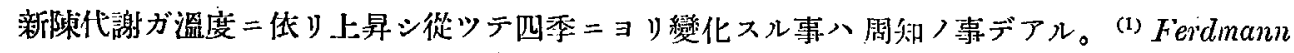

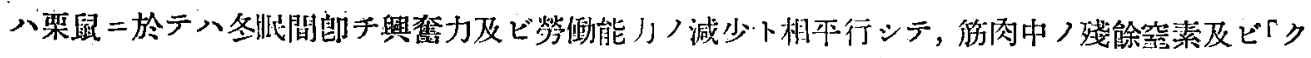

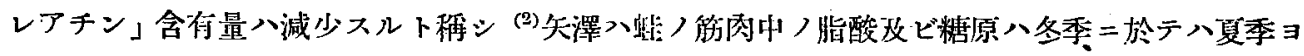
リ多量デ伤肉中「クレアチシ」「クレアチニン」ハ活動期 $=$ 於テ次筙二增加シ 8 月最大二達シ爾後

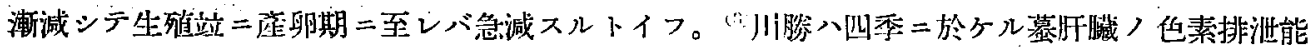

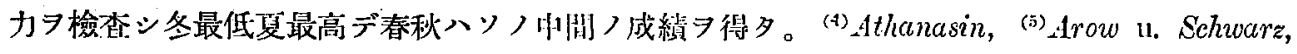

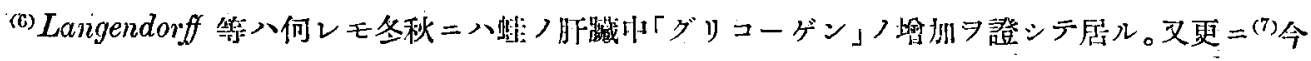

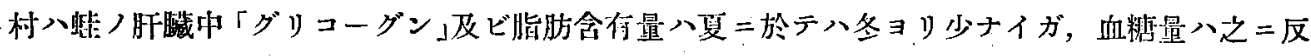

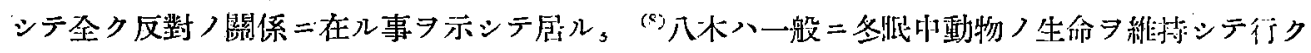

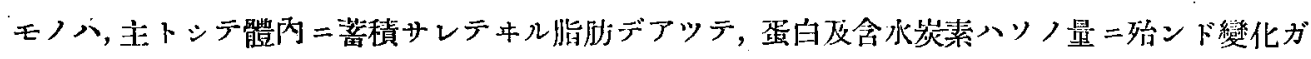

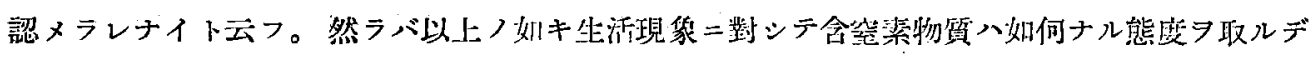

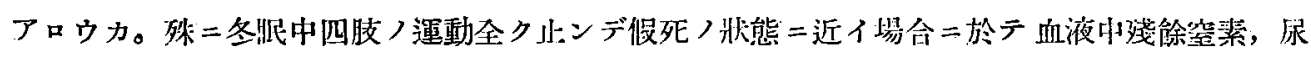

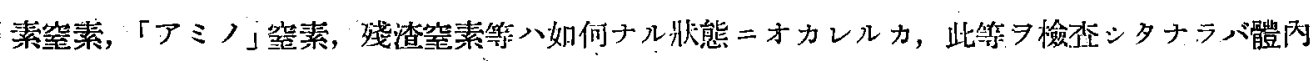

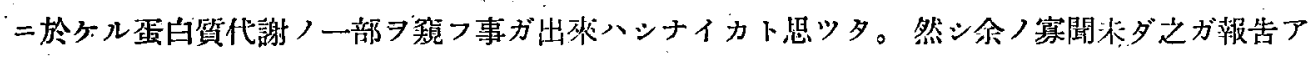

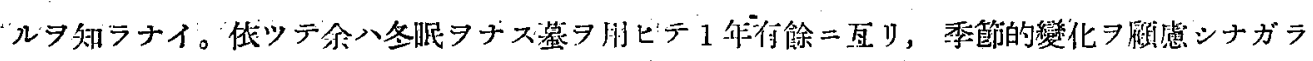

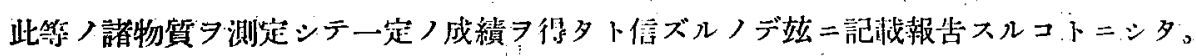

\section{(2) 實 驗 方 法}

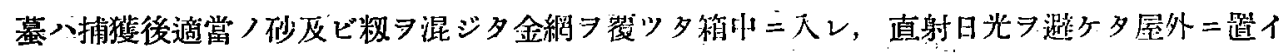

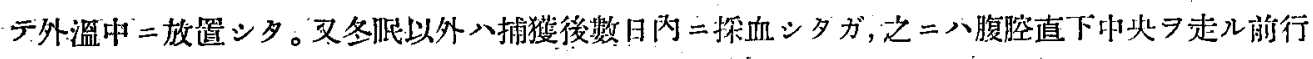

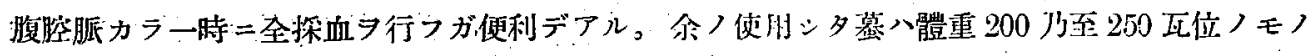

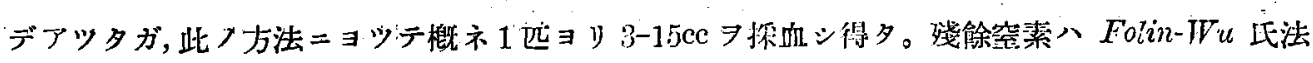




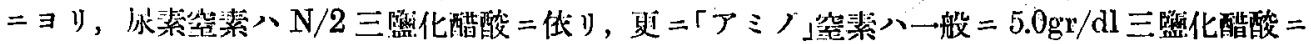

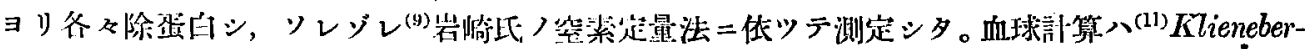

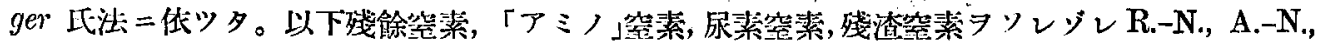

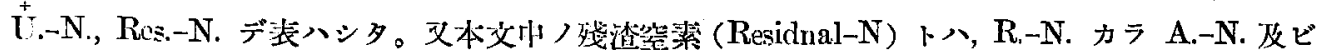

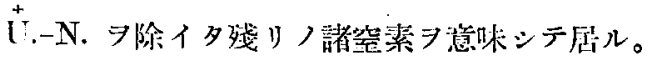

\section{（3） 月別及ビ氣溫別各窒素/相互關係}

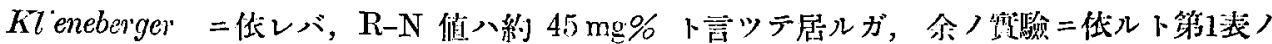

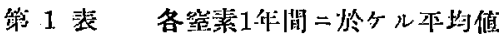

\begin{tabular}{|c|c|c|c|c|}
\hline $\mathrm{R}-\mathrm{Nmg} \%$ & $\mathrm{~A}-\mathrm{N} n \mathrm{~g} \%$ & $\mathrm{U}-\mathrm{N} m \mathrm{~g} \%$ & $\operatorname{Re}-\mathrm{N} u g \%$ & 㒒栲 \\
\hline . 192.85 & 17.73 & 175.16 & 35.50 & 最火値 \\
\hline 40.00 & 7.00 & 15.00 & 2.66 & 昆小颠 \\
\hline 85.12 & 11.60 & 63.87 & 16.59 & 平均值 \\
\hline
\end{tabular}
如り 132 例二就イテ 1 年間习通

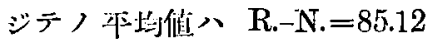
$\mathrm{mg} \%$; $\Lambda .-\mathrm{N} .=11.62 \mathrm{mg} \%$; U.$\mathrm{N} .=63.87 \mathrm{mg} \% ;$ Res. $-\mathrm{N} .=16.59$ mg3o トナリ前答ヨリ相賞大キ イ値习得テねル。

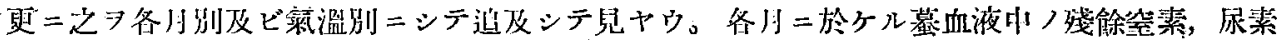

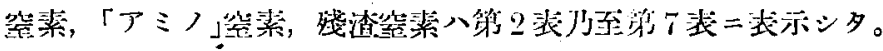

第 2 裴 1 月炎ビ 2 月二於ヶル各䇺猄倠

\begin{tabular}{|c|c|c|c|c|c|c|c|c|}
\hline 番 & $\begin{array}{l}\text { 鸪 } \\
\mathrm{H}\end{array}$ & 性 & $\begin{array}{l}\text { 炼 } \\
\text { 滥 }\end{array}$ & $\begin{array}{l}\mathrm{R}-\mathrm{N} \\
\mathrm{mg} \%\end{array}$ & $\begin{array}{l}A-N \\
\text { ing } \%\end{array}$ & $\begin{array}{l}\stackrel{+}{\mathrm{U}}-\mathbf{N} \\
\mathrm{mg} \%\end{array}$ & $\begin{array}{l}\text { Re: }-N_{1} \\
\mathrm{mg} ;\end{array}$ & 候 \\
\hline $\begin{array}{r}1 \\
3 \\
3 \\
7 \ddot{7} \\
75 \\
76\end{array}$ & $\begin{array}{c}21 / 1 \\
23 / \mathrm{I} \\
1 \ddot{2} / \mathrm{I} \\
", \\
",\end{array}$ & 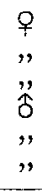 & $\begin{array}{l}4^{\circ} \\
", \\
", \\
", \\
",\end{array}$ & $\begin{array}{l}64.24 \\
68.08 \\
59.07 \\
63.78 \\
60.10 \\
59.12\end{array}$ & $\begin{array}{r}10.19 \\
8.79 \\
8.90 \\
9.99 \\
7.90 \\
8.20\end{array}$ & $\begin{array}{l}46.93 \\
47.00 \\
40.17 \\
44.70 \\
87.00 \\
39.00\end{array}$ & $\begin{array}{r}7.12 \\
1.39 \\
10.00 \\
9.79 \\
16.15 \\
11.9 *\end{array}$ & 오살 小 \\
\hline \multicolumn{4}{|c|}{1 月總平均 } & 62.37 & $8.88^{\prime}$ & 48.46 & 11.21 & \\
\hline 1 & $\begin{array}{ll}\text { 月 } & ? \\
\text { H } & \text { 学 }\end{array}$ & 平 & & $\begin{array}{r}63.78 \\
60.96 \\
\end{array}$ & $\begin{array}{l}9.29 \\
8.48\end{array}$ & $\begin{array}{l}44.70 \\
40.20\end{array}$ & $\begin{array}{r}9.80 \\
12.6\end{array}$ & \\
\hline $\begin{array}{r}77 \\
78 \\
79 \\
80 \\
4 \\
5 \\
6 \\
7 \\
8 \\
9 \\
10 \\
11 \\
1\end{array}$ & $\begin{array}{c}4 / \mathbf{I I} \\
", \\
", \\
7 / \mathbf{I I} \\
", \\
", \\
1 \% \text { II } \\
3 / \text { II } \\
, " \\
",\end{array}$ & 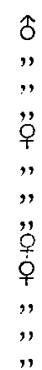 & $\begin{array}{l}4^{\circ} \\
", \\
", \\
3^{\circ} \\
", \\
", \\
6^{\circ} \\
3^{\circ} \\
", \\
",\end{array}$ & $\begin{array}{l}59.80 \\
50.70 \\
65.00 \\
84.50 \\
66.30 \\
40.00 \\
43.20 \\
48.38 \\
66.56 \\
69.50 \\
61.10 \\
67.60 \\
60.10\end{array}$ & $\begin{array}{r}10.06 \\
7.85 \\
8.51 \\
8.25 \\
9.54 \\
7.25 \\
8.00 \\
8.97 \\
9.60 \\
9.08 \\
5.90 \\
9.08 \\
8.51\end{array}$ & $\begin{array}{l}22.30 \\
31.08 \\
37.20 \\
68.20 \\
43.00 \\
23.00 \\
25.42 \\
27.57 \\
50.34 \\
30.76 \\
34.72 \\
40.30 \\
42.49\end{array}$ & $\begin{array}{r}27.49 \\
22.47 \\
19.29 \\
-8.05 \\
13.76 \\
10.46 \\
10.78 \\
11.79 \\
4.62 \\
29.71 \\
17.48 \\
18.27 \\
9.10\end{array}$ & 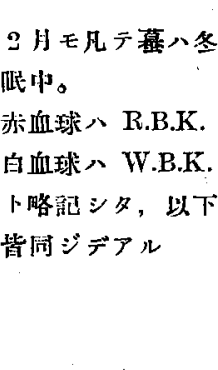 \\
\hline 13 & 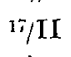 & 우 & $10^{\circ}$ & 69.10 & $8.04:$ & 44.40 & 16.06 & 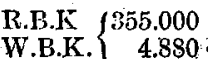 \\
\hline 14 & $"$ & $"$ & $"$ & 72.60 & $11.90^{\circ}$ & 86.00 & $24.70^{\prime}$ & 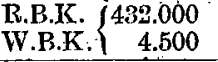 \\
\hline
\end{tabular}

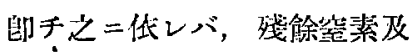

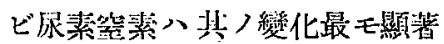
二現ハレ，1月2月3月ノ冬脈 中八此等:值小デアルガ，4月

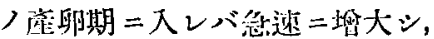
1 年ヨ逊ジテ最大トナル コトガ出來ル。之ハ必ズシモ外 界氣溫上景ナドデ淠朋スべキモ ノデハナイ。例へバ第 3 韭ノ䓪 No. $15,16,17,>3$ 匹八䠶 $=3$ 月二商卵シタノデ R.-N. モ -N. モ他ノ總デ䓪ヨリ溚シク 大ナル值 示シテ居ルコトガ明 デアル。又外溫八同ジデモ同上 表 No. 87-90，疗ビ No. 8384,笋八R.-N., 及ビ Ů.-N., 共= 前 3 省ノ快量ニモ湭シナイコト ヨ見ルコトガ出隶ル。殊二興味 


\begin{tabular}{|c|c|c|c|c|c|}
\hline 2月總平均 & $61: 61$ & 8.89 & 36.27 & 15.57 & \\
\hline 2 月 우 平均 & 60.39 & 9.03 & 36.12 & 15.15 & 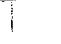 \\
\hline 卫月古平均 & 65.00 & 8.54 & 36.70 & 16.75 & $\therefore$ \\
\hline
\end{tabular}

鉒 3 裴 3 月二於ヶル各雜素怵

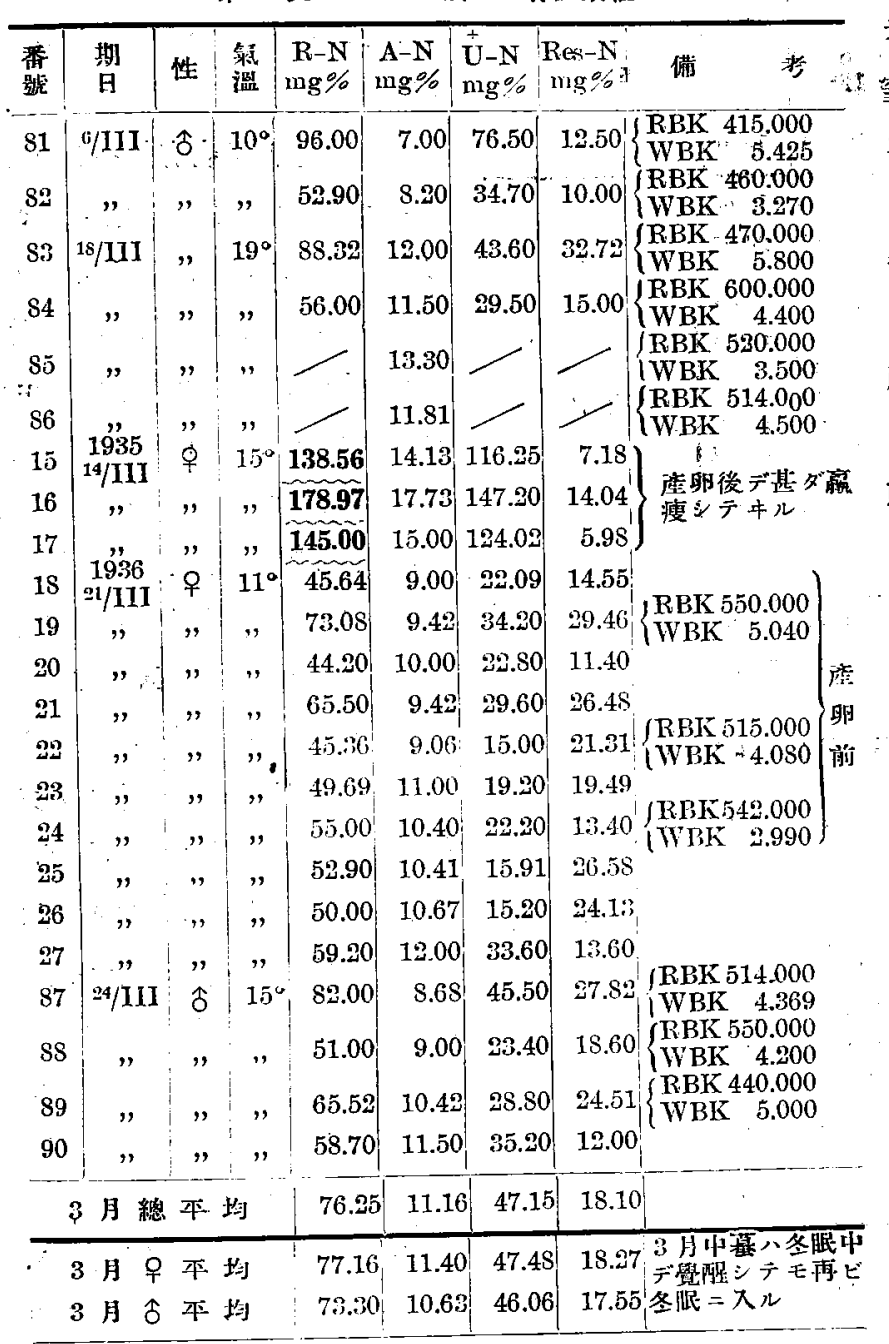

第 4 裴 4 月及ビ 5 月二於ケル各紫素值

\begin{tabular}{|c|c|c|c|c|c|c|c|c|c|}
\hline 番 & 期 & 珄 & $\begin{array}{l}\text { 嶻 } \\
\text { 盘 }\end{array}$ & $\begin{array}{l}\mathrm{R}-\mathrm{N} \\
\mathrm{mg} \%\end{array}$ & $\begin{array}{c}\mathrm{A}-\mathrm{N} \\
\mathrm{mg} \%\end{array}$ & $\begin{array}{l}\overline{\mathrm{U}}-\mathrm{N} \\
\mathrm{mg} \%\end{array}$ & $\begin{array}{c}\operatorname{Res}-\mathrm{N} \\
\mathrm{mg} \%\end{array}$ & 洲 & 榙 \\
\hline 91 & $\begin{array}{l}1935 \\
98 / 1 V\end{array}$ & 今 & $20^{\circ}$ & 68.75 & 12.64 & 5.45 & 3.66 & & \\
\hline 92 & & & ", & 95.76 & 13.36 & 48.00 & 29.40 & & \\
\hline 93 & 1936 & ט & ," & 142.50 & 9.81 & 89.00 & 52.79 & & \\
\hline 94 & $\eta^{-}$ & , & ,, & 105.76 & 10.16 & 75.60 & 17.00 & & \\
\hline
\end{tabular}

ガ倠ルノ八 No.18-27ノ10 匹

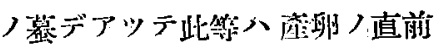
デアッタ＝モ拘ラズ，“脩此等ノ 值ガ頡シク小デケルトムフコト

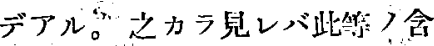

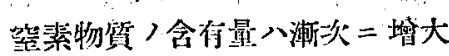
スルト云フ譯デハナグ"竞卵期

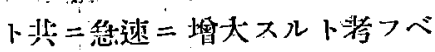
キデアラウ。

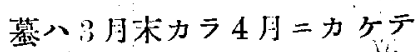

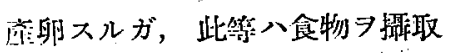

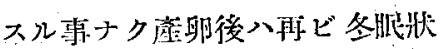
態二大ルモノデアル。然シ此等

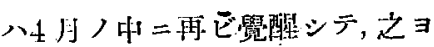
リ渠人ガ普通㫕ル活動狀熊二入 ルモノデアル。此ノ活動狀態ノ

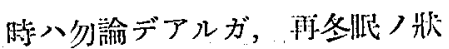
態卜踓毛初邓ノ本來, 冬胀期,

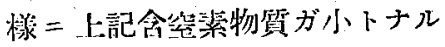
モノデハナイ。此ノ期間 =八非

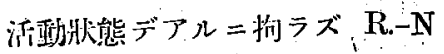

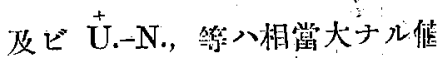
ヨ䒹シテ磨ルノデ, 4 月二测定セ 凡モノ八1 ケ年フ通ジテ最弇;

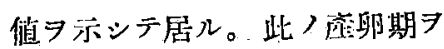
過シテ秋期マデハ，致〉活洨二

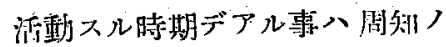
通りデアルガ，此ノ間ノ， R.-N.,

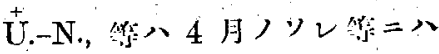
及バナイガ然シ仃ナy 大量二含

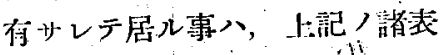

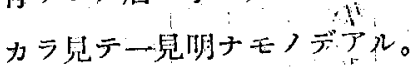
然シ 11 月ヨリ雨ど冬狀二大ル 


\begin{tabular}{|c|c|c|c|c|c|c|c|c|}
\hline 95 & & & ", & 173.85 & 11.65 & $14 \overline{.20}$ & 13.00 & \multirow{9}{*}{ 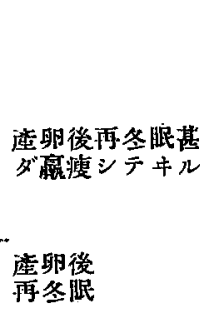 } \\
\hline 28 & $\begin{array}{l}1935 \\
2 / 1 V\end{array}$ & & $24^{\circ}$ & 124.11 & 13.08 & 84.80 & 26.23 & \\
\hline 29 & Q6/TV: & & $20^{\circ}$ & 180.00 & $16.01^{\prime}$ & & & \\
\hline 30 & , & ", & " & 192.25 & 13.67 & 175.16 & 3.42 & \\
\hline 31 & & , & , & 165.41 & 12.12 & 149.00 & 3.29 & \\
\hline 32 & 1936 & $"$ & $"$ & 179.12 & & 16091 & 3.59 & \\
\hline 33 & $\begin{array}{l}1836 \\
26 / I V\end{array}$ & 우 & $20^{\circ}$ & 131.50 & 14.80 & 92.40 & 24.30 & \\
\hline 34 &,$\quad \vdots$ & " & " & 118.50 & 13.16 & 85.20 & 20.39 & \\
\hline & ") & $"$ & $"$ & & & 128.00 & 21.50 & \\
\hline \multicolumn{4}{|c|}{4 月總平均 } & 141.81 & 13.20 & 106.56 & 18.16 & \\
\hline \multirow{2}{*}{\multicolumn{4}{|c|}{$\begin{array}{l}4 \text { 月 } \text { 平平均 } \\
4 \text { 月 合平均 }\end{array}$}} & 157.01 & 14.13 & 185.06 & 14.66 & \\
\hline & & & & 117.32 & 11.79 & 80.65 & $\mathbf{8 4 . 5 7}$ & \\
\hline 36 & $\begin{array}{l}1935 \\
19 / V\end{array}$ & ㅇ & $22^{\circ}$ & 116.50 & 10.48 & 99.60 & 6.48 & \multirow{8}{*}{ 再ビ覺醒スル } \\
\hline 37 & ", & " & ", & 126.00 & 13.30 & 102.70 & 10.00 & \\
\hline 38 & & , & $"$ & 118.75 & 15.52 & \begin{tabular}{|l|}
97.32 \\
\end{tabular} & 5.91 & \\
\hline 96 & $4 / \mathrm{V}$ & ई & ", & 89.90 & 9.83 & 74.12 & 5.73 & \\
\hline 97 & & ," & ", & 57.12 & 10.99 & 30.20 & 15.93 & \\
\hline 98 & $16 / \mathrm{V}$ & $"$ & ", & 63.00 & 11.04 & 35.96 & 15.00 & \\
\hline 99 &, & ", & " & 97.65 & 12.52 & 59.52 & 25.61 & \\
\hline 100 &, & $"$ & $"$ & 90.12 & 12.00 & 60.12 & 18.00 & \\
\hline \multicolumn{4}{|c|}{5 月總“本均 } & 80.46 & 11.26 & 57.70 & 15.47 & \\
\hline \multirow{2}{*}{\multicolumn{4}{|c|}{$\begin{array}{lll}5 & \text { 月 } & \text { 平 均 } \\
5 & \text { 月 } & \text { 合 均 }\end{array}$}} & 120.41 & 13.08 & 99.87 & 7.46 & \\
\hline & & & & 78.77 & 10.66 & 43.63 & 18.15 & \\
\hline
\end{tabular}

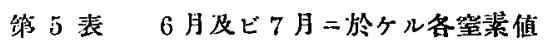

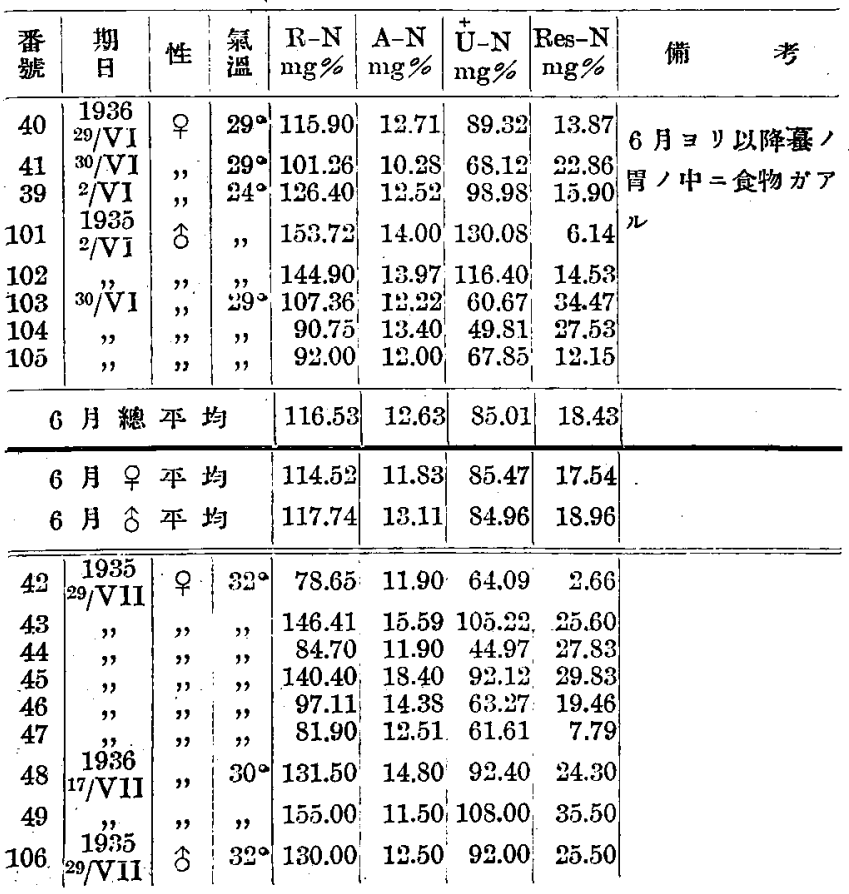

ガ，乙ト同跀二血液中ノ此等含

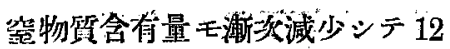
月二至レバ，1月2月ノ值ト大 耾ナイ位二減少スルモノデア

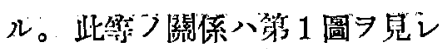
バ明膫デアル。

「アミノ」酸ノ含有量八上記二

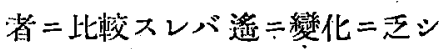
イ毛デアル。然シ 3 月4月ノ 㕍卵期 期二堌杊スルコトハ事實デアロ ウ。然シ春二現ハレテ居ル程顯

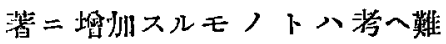
人。余八時閌入不足卜血液量モ 大デナカツタノデ $\mathrm{NH}_{3}$ ，定量 八省略シタガ, 此ノ $\mathrm{NH}_{3}-\mathrm{N}$ 八 刨諭， U.-N. ノ少部八，今日ノ A. -N. 定量法二排ツテ柬方ノデ 100-150mg\% モ存スル U. U.つ一部八留モA.-N. デアルガ如 ク現ハレテ居ルノ＝相造ナイ。 從ツテ棶來ナラバ瓦素》除去シ

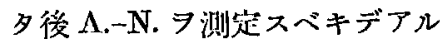
ガ，赤八時間不起つ爲二此ノ事 ヨナシ得ナカツ夕。

故二表示シタモノ八實際ノ $\mathrm{A}$. 一N. ヨリモ僅カニ大ナル值ガ出 テ居ル笟デアル。然シ其つ差入 僅微デアララウ。第 3 表及ビ第4

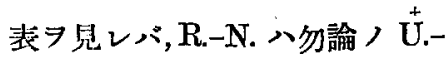
N. ノ值ガ份小デアルニモ拘 ズ A.-N. 八值八朁二明二繒大シ タ傾 示シテ居ルカラデアル。 


\begin{tabular}{|c|c|c|c|c|c|c|c|}
\hline $\begin{array}{l}107 \\
108\end{array}$ & $"$ & $"$ & ", & $\begin{array}{r}88.54 \\
114.45\end{array}$ & $\begin{array}{l}14.64 \\
13.87\end{array}$ & $\begin{array}{l}5.3 .67 \\
97.71\end{array}$ & $\begin{array}{l}21.83 \\
20.87\end{array}$ \\
\hline 7 & 月 & 平 & & 113.51 & 13.81 & 77.80 & 21.87 \\
\hline .7 & 月 & 來 & & 114.45 & 13.87 & 78.96 & 21.62 \\
\hline 7 & 月 & 平 & & 110.99 & 13.67 & 74.79 & 99.55 \\
\hline
\end{tabular}

第 6 表 8 月改ビ 9 月二於ヶル各啙素値

\begin{tabular}{|c|c|c|c|c|c|c|c|c|}
\hline 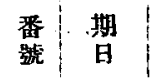 & 性 & 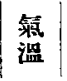 & $\begin{array}{l}\mathrm{R}-\mathrm{N} \\
\mathrm{mg} \%\end{array}$ & $\begin{array}{l}\mathrm{A}-\mathrm{N} \\
\mathrm{mg} \%\end{array}$ & 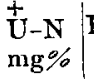 & $\left|\begin{array}{c}\text { Res.-N } \\
\mathrm{mg} \%\end{array}\right|$ & 偀 & 考 \\
\hline 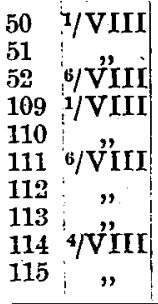 & $\begin{array}{l}\text { + } \\
", \\
\text { 人 } \\
", \\
", \\
", \\
",\end{array}$ & 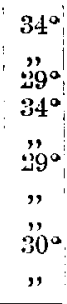 & $\begin{array}{r}126.26 \\
113.77 \\
97.44 \\
107.38 \\
141.04 \\
84.00 \\
60.48 \\
97.54 \\
79.06 \\
9: 04\end{array}$ & $\begin{array}{l}13.09 \\
16.31 \\
11.06 \\
16.00 \\
15.00 \\
11.90 \\
11.66 \\
12.1 \\
13.64 \\
10.90\end{array}$ & $\begin{array}{r}103.04 \\
86.46 \\
79.35 \\
79.07 \\
93.55 \\
60.00 \\
33.64 \\
77.35 \\
54.99 \\
58.80\end{array}$ & $\begin{array}{r}10.13 \\
11.00 \\
6.03 \\
13.31 \\
31.54 \\
12.60 \\
15.18 \\
8.02 \\
11.49 \\
22.24\end{array}$ & $\left\{\begin{array}{l}\text { RBK } \\
\text { WBKK }\end{array}\right.$ & $\begin{array}{r}360.000 \\
4.100\end{array}$ \\
\hline S 月 總 & 平 & & 99.59 & 13.06 & 72.63 & 13.99 & & \\
\hline $\begin{array}{lll}8 & \text { 月 } & \text { 9 } \\
8 & \text { 月 } & \text { 今 }\end{array}$ & 平 & & $\begin{array}{r}112.46 \\
94.50\end{array}$ & $\begin{array}{l}13.48 \\
12.88\end{array}$ & $\begin{array}{l}89.61 \\
65.35\end{array}$ & $\begin{array}{r}9.05 \\
16.11\end{array}$ & & \\
\hline 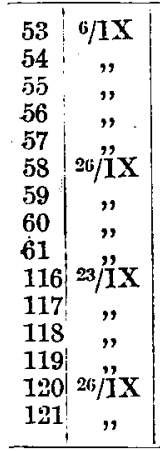 & 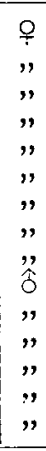 & 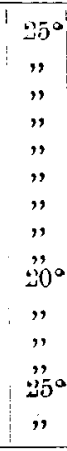 & \begin{tabular}{|r|}
102.44 \\
147.6 \\
108.58 \\
143.48 \\
130.30 \\
81.60 \\
85.20 \\
103.00 \\
156.00 \\
79.64 \\
109.62 \\
90.09 \\
76.75 \\
108.00 \\
81.40
\end{tabular} & $\begin{array}{r}13.53 \\
14.99 \\
15.83 \\
13.51 \\
17.37 \\
13.20 \\
14.39 \\
15.00 \\
16.50 \\
11.41 \\
8.68 \\
9.30 \\
10.15 \\
14.75 \\
13.32\end{array}$ & \begin{tabular}{|r|r|}
73.44 \\
111.55 \\
87.62 \\
125.92 \\
91.42 \\
56.93 \\
49.84 \\
59.72 \\
130.87 \\
48.00 \\
79.26 \\
61.80 \\
46.60 \\
69.81 \\
62.01 \\
53.0
\end{tabular} & \begin{tabular}{|r|}
15.48 \\
21.08 \\
5.13 \\
4.05 \\
21.51 \\
11.47 \\
20.87 \\
27.28 \\
8.63 \\
20.23 \\
21.68 \\
18.99 \\
20.00 \\
23.44 \\
6.07
\end{tabular} & $\left\{\begin{array}{l}8 \text { 月量 } \\
\text { 夕基 } \\
\text { ナ1, } \\
\text { シテ }\end{array}\right.$ & 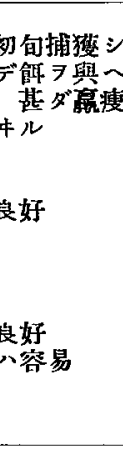 \\
\hline 9 月 總 & 平 & & 106.50 & 13.40 & 76.98 & 16.03 & & \\
\hline 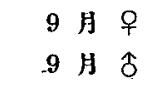 & $\begin{array}{l}\text { 平 } \\
\text { 平 }\end{array}$ & & $\begin{array}{r}117.46 \\
90.90\end{array}$ & $\begin{array}{l}14.86 \\
11.26\end{array}$ & S7.47 & $\begin{array}{l}15.03 \\
18.40\end{array}$ & & \\
\hline
\end{tabular}

第 7 表 10 月 11 月及ビ 12 月二於ケル各空素值

\begin{tabular}{|c|c|c|c|c|c|c|c|c|c|}
\hline $\begin{array}{l}\text { 粮 } \\
\text { 號 }\end{array}$ & 期 & 性 & $\begin{array}{l}\text { 氮 } \\
\text { 温 }\end{array}$ & $\begin{array}{l}\mathrm{R}-\mathrm{N} \\
\mathrm{mg} \%\end{array}$ & $\begin{array}{c}\mathrm{A}-\mathrm{N} \\
\mathrm{mg} \%\end{array}$ & $\begin{array}{l}\stackrel{+}{\mathrm{U}}-\mathrm{N} \\
\mathrm{mg} \%\end{array}$ & $\mid \begin{array}{c}\text { Res-N } \\
\text { mg\% }\end{array}$ & 供 & 芳 \\
\hline $\begin{array}{r}62 \\
63 \\
64 \\
122 \\
123 \\
124 \\
125\end{array}$ & $\begin{array}{c}18 / \mathbf{X} \\
", \\
", \\
" \\
" \\
"\end{array}$ & $\begin{array}{l}\text { 早 } \\
\text { " } \\
\text { "र } \\
\text { ", } \\
":\end{array}$ & $\begin{array}{l}24^{\circ} \\
" \\
" \\
" \\
" \\
"\end{array}$ & $\begin{array}{r}104.86 \\
115.05 \\
95.00 \\
98.82 \\
99.80 \\
81.74 \\
119.08\end{array}$ & $\begin{array}{l}12.16 \\
13.55 \\
11.00 \\
12.34 \\
11.73 \\
11.61 \\
12.58\end{array}$ & $\begin{array}{l}74.70 \\
81.41 \\
66.50 \\
66.35 \\
59.07 \\
48.26 \\
88.11\end{array}$ & $\begin{array}{l}18.00 \\
20.09 \\
17.50 \\
20.13 \\
29.80 \\
21.87 \\
18.39\end{array}$ & & \\
\hline
\end{tabular}

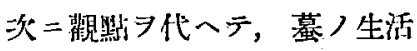
スル外界ノ温度习中心トシテ此

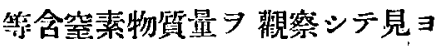
ウ。大體二於テ渼力ラ夏ニカケ

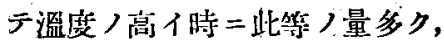
冬ノ時ニ小デア゙ル事ハ間邁ナイ ガ, 然シ外框ノ溫度ノミニ依ツ テ支配サレルモノデハナイラシ イ。此ノ關係八第 2 圖 7 見レバ 明デアルガ, 泰期ノ $16^{\circ}$ 乃至 $20^{\circ}$ ノ㭙ガ最大デ R.-N. 八 133 $\mathrm{mg}$ \% デアルノ 乃至 $16^{\circ}$ 間ノ場合 $=八$ 嚾 $=89$ mg\% デアル。㽷秦文ビ「アミノ」 酸モ此入關係二八異ナル所ガナ 人,又5月カラ 7 月二涉レル $21^{\circ}$ -30 入氣溫卜 8 月カラ 10 月二挂 ケテノ同一温度ノ場合ニ於テハ

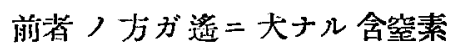
物質 $フ$ 血液中 =見出スデアラ ウ。多本 $=3$ 月 4 月八產卵期, 生 殖期ニ八渵度习超越シ夕等速ナ 桨玔カ現ハレルモノデアル。然 シ冬胍時期 低溫つ場合二八常

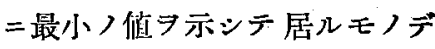
アル。從ツテ此等ノ值ガ冬经ノ 泒動停止つ期閒ハ小デアツテ溫 度つ高イ彼等つ活動期ニ大デア ルノハ間遠ナイ事䁈デアルガ, 然シ其外二更三重大ナル因子， 存スル事习忘レテハナラナイ。 ソレハ被管)生殖期ト云フ事デ

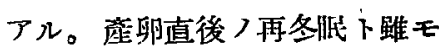




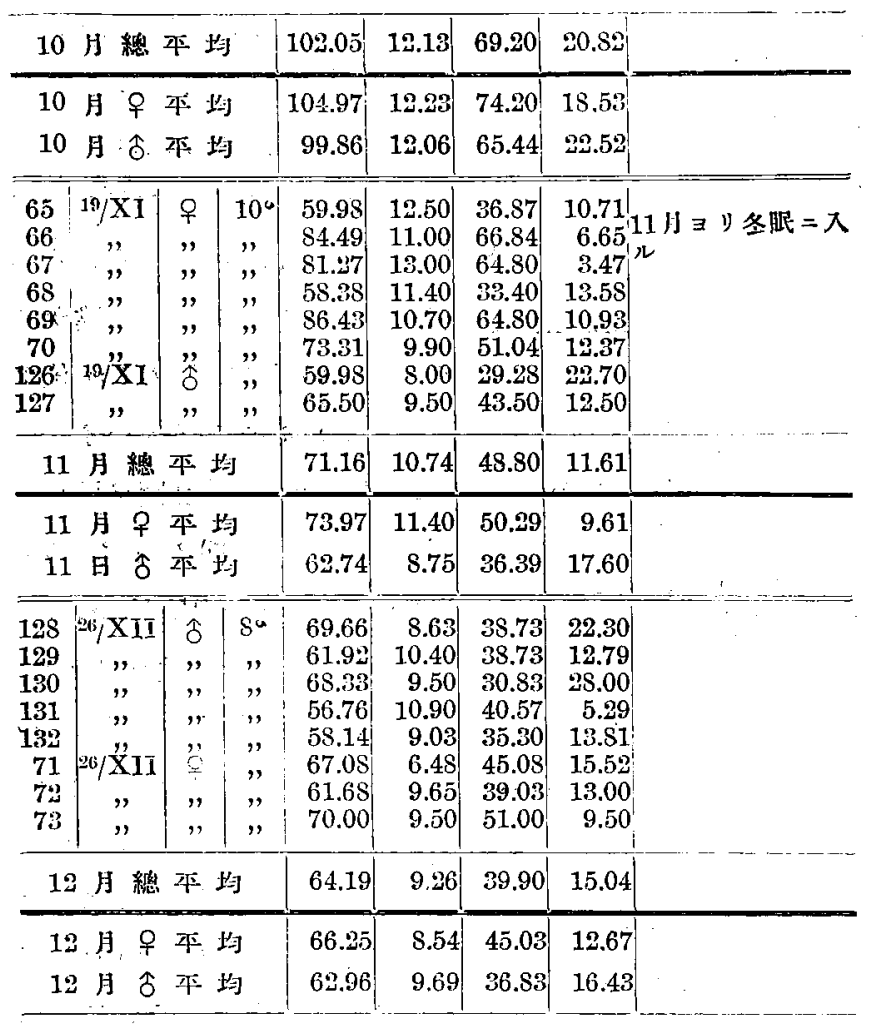

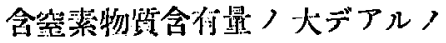
八興味アル事デアル。 今村八濦二於らル 血糖量、冬 怍期二少ナク, 㚆多倳 7 發見 シタガ, 管素代謝二近イ關係习 驸スルト思ハレル血液印〉上記 含突素物質モ亦芠り同ジ條作二 ヨツテ變化スルモノト思ハレ ル。

以上ノ結柴力ラ夏期外祭ノ温 度ガ㗬イ時從ツテ墓つ體溫モ亦 高入時二血液中八殘餘空素，尿 素灭ビ「アミノ」酸等が多クナル 事八謂ノナイ事蜜デアル。と八

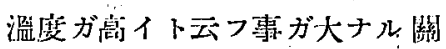
係ガアル柡二モ思ハレルガ然シ 此入時期二八㗢物入運動モ亦最 モ沫潑デアルカラ，篇二䉼随代

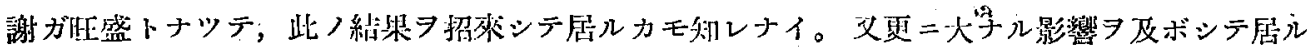

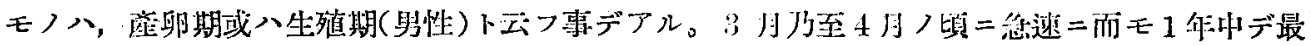
高ノ值ヨ亦スト云フ事ハ此ノ考の證明スルモノト先テ差䒝ナイデアラウ。

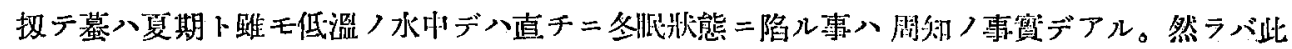

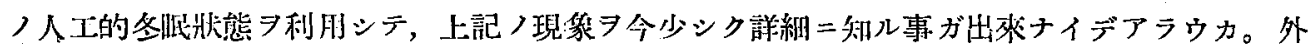

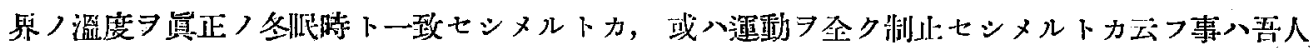
ノ希望通 $リ=$ 調節出來ル摆デアル。

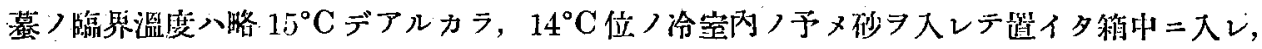

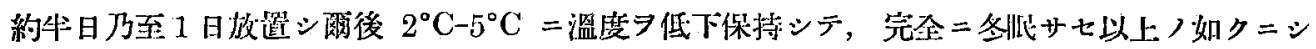

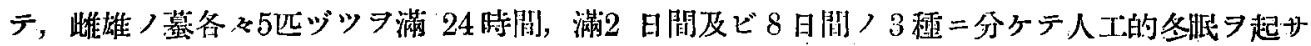

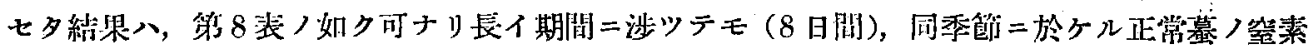

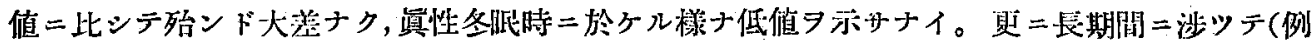

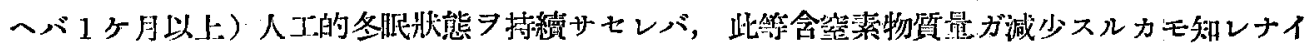

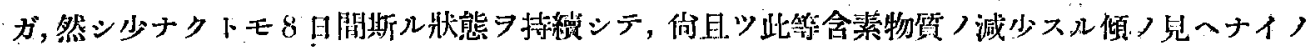

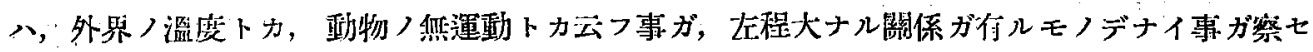


第 1 阅 月别諸突素相五關保

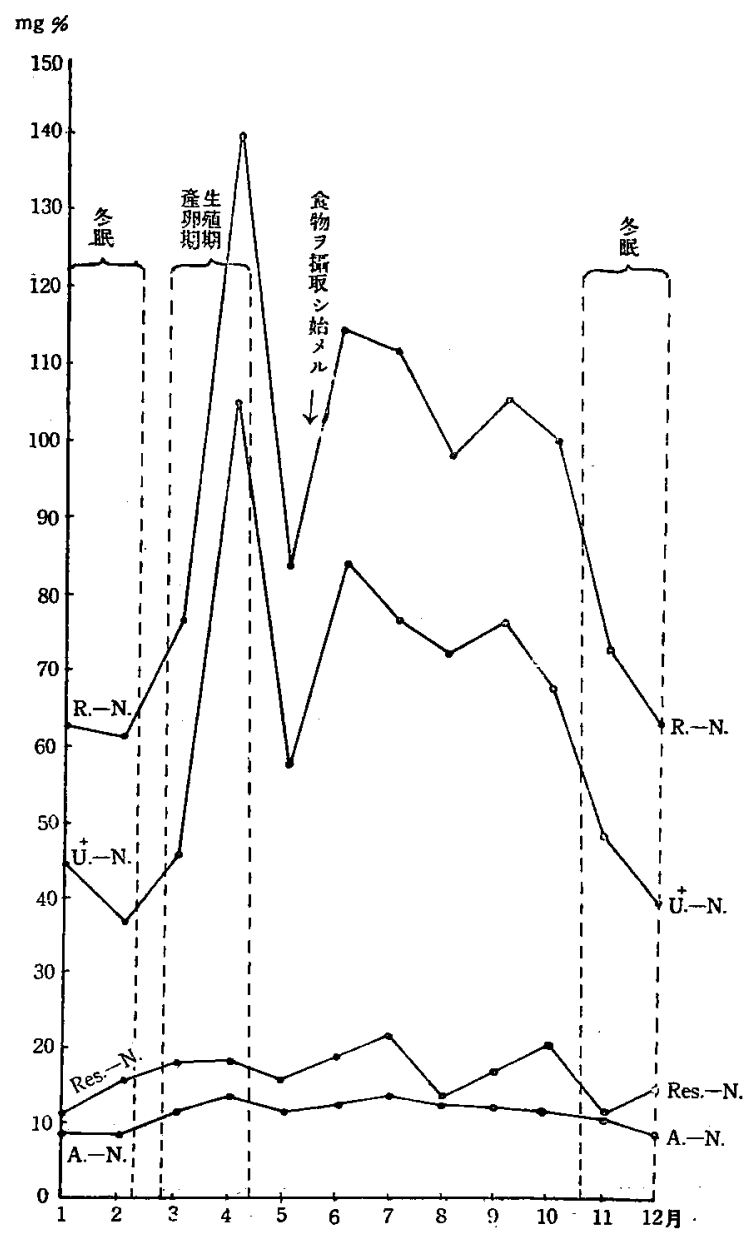

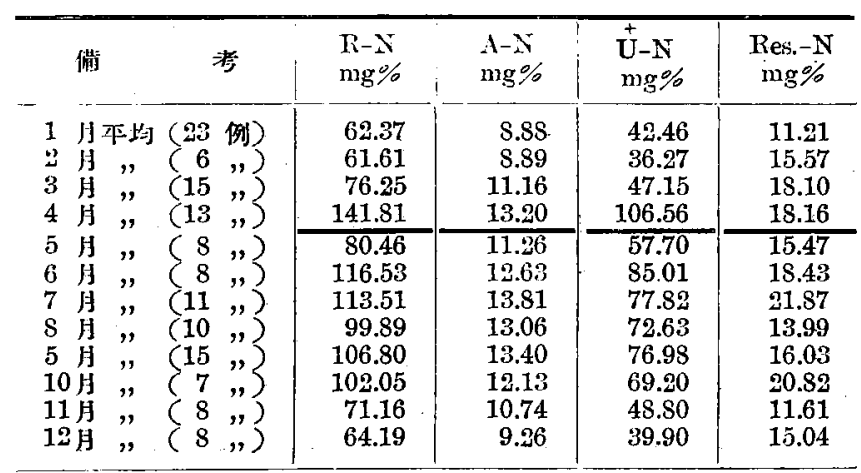

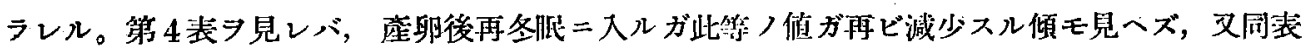

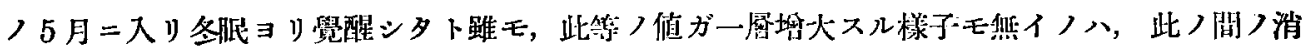




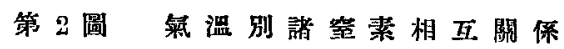

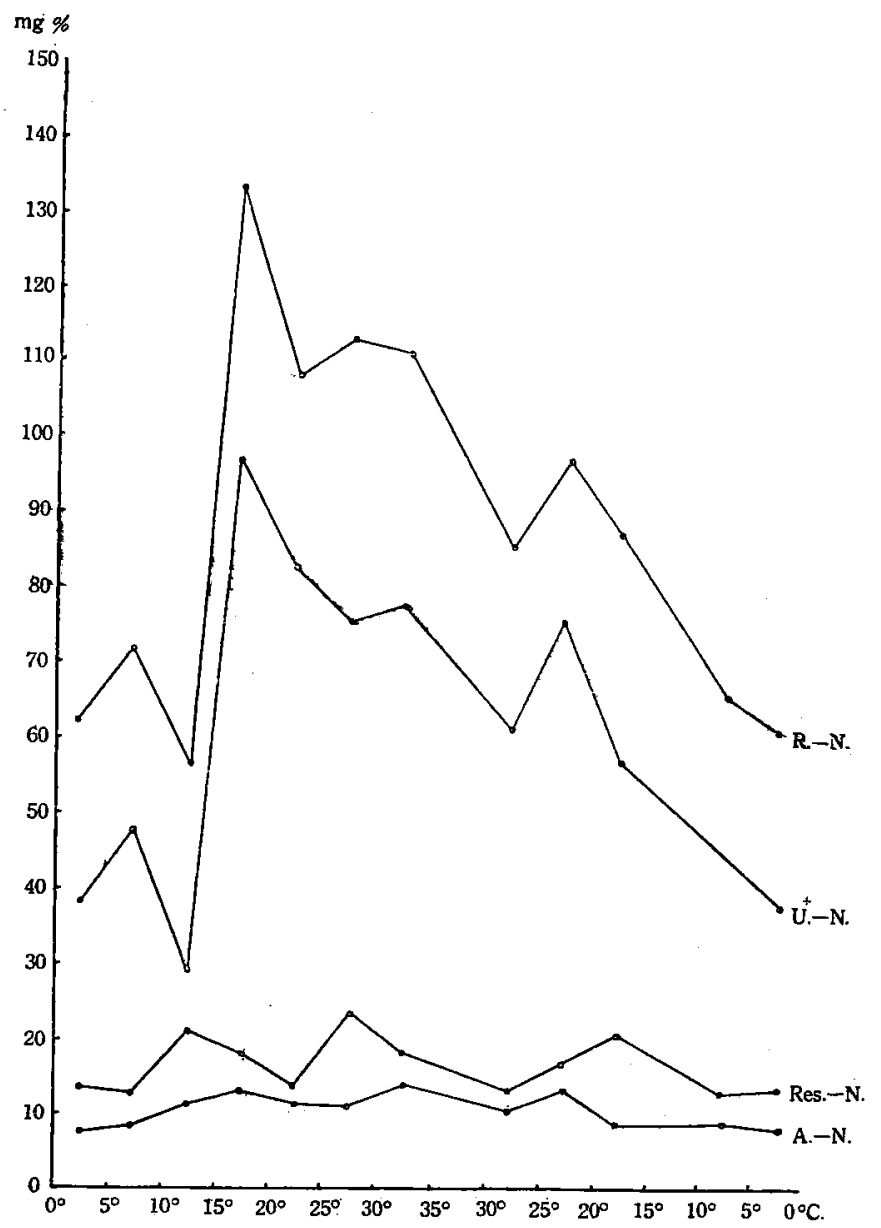

\begin{tabular}{|c|c|c|c|c|c|c|}
\hline 氣溫 & $\begin{array}{l}\mathrm{R}-\mathrm{N} \\
\mathrm{mg} \%\end{array}$ & $\begin{array}{l}\mathrm{A}-\mathrm{N} \\
\mathrm{mg} \%\end{array}$ & $\begin{array}{l}\dot{U}-N \\
\text { mg } \%\end{array}$ & $\begin{array}{c}\operatorname{Res}^{*}-\mathrm{N} \\
\mathrm{mg} \%\end{array}$ & 月 & \\
\hline $0^{\circ}-5^{\circ}$ & 61.14 & 8.70 & 37.23 & 14.75 & 1月2月 & \\
\hline $6^{\circ}-10^{\circ}$ & 71.43 & 9.06 & 48.38 & 13.57 & $2-3$ 月 & 腿 \\
\hline $11^{\circ}-15^{\circ}$ & 56.98 & 10.07 & 25.90 & 20.95 & 3 月 & \\
\hline $16^{\circ}-20^{\circ}$ & 133.05 & 12.88 & 97.46 & 18.46 & $3-4$ 月 & 轪卵期 \\
\hline $21^{\circ}-25^{\circ}$ & 109.01 & 12.43 & 82.48 & 13.78 & $5-6$ 月 & \\
\hline $26^{\circ}-30^{\circ}$ & 113.39 & 12.41 & 76.59 & 24.38 & $6-7$ 月 & \\
\hline $31^{\circ}-35^{\circ}$ & 111.58 & 14.31 & 78.29 & 18.91 & $7-8$ 月 & 食物 7 取 \\
\hline $30^{\circ}-26^{\circ}$ & 85.09 & 11.71 & 62.20 & 11.18 & 8 月 & ル \\
\hline $25^{\circ}-21^{\circ}$ & 109.05 & 13.74 & 77.97 & 17.26 & 9-10月 & \\
\hline $20^{\circ}-16^{\circ}$ & 89.03 & 9.88 & 58.73 & 20.22 & 9 一月 & \\
\hline $10^{\circ}-6^{\circ}$ & 67.64 & 1000 & 44.55 & 13.32 & 11-12月 & 阯 \\
\hline
\end{tabular}

息ヨ語ルモノデ獄ツテ，上記ダケノ成績カラ見レバ, 産卵(或八生殖)ト云フ作朋ガ最モ大ナル 影響ヨ及ボシテ居ルモノノ㥞二思ハレル。 


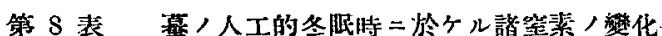

\begin{tabular}{|c|c|c|c|c|c|c|c|c|}
\hline $\begin{array}{l}\text { 番 } \\
\text { 號 }\end{array}$ & 㫷 & 性 & $\begin{array}{l}\text { 外 } \\
\text { 牙 } \\
\text { 温 } \\
\end{array}$ & $\begin{array}{l}\mathbf{R}-\mathbf{N} \\
\mathrm{mg} \%\end{array}$ & $\begin{array}{l}\mathrm{A}-\mathrm{N} \\
\mathrm{mg} \%\end{array}$ & $\begin{array}{l}+ \\
\mathbf{U}-\mathbf{N} \\
\mathbf{m g} \%\end{array}$ & $\mid \begin{array}{c}\text { Res-N } \\
\text { mg\% } \%\end{array}$ & 備 \\
\hline $\begin{array}{l}135 \\
136 \\
137 \\
135 \\
139\end{array}$ & $\begin{array}{c}26 / V I I I \\
26 / V I I I \\
1 / I X \\
", \\
"\end{array}$ & 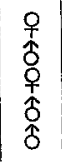 & $\begin{array}{c}29 .{ }^{\circ} \mathrm{C} \\
3{ }^{\circ}{ }^{\circ} \mathrm{C} \\
" \\
"\end{array}$ & $\begin{array}{r}89.90 \\
93.60 \\
108.00 \\
126.00 \\
116.40\end{array}$ & $\begin{array}{l}14.69 \\
10.78 \\
10.17\end{array}$ & $\begin{array}{l}40.15 \\
60.50 \\
76.80 \\
78.00 \\
85.20\end{array}$ & $\begin{array}{l}18.41 \\
20.42 \\
37.83\end{array}$ & 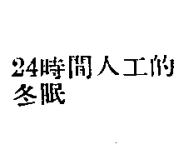 \\
\hline \multicolumn{4}{|c|}{ 以上 5 例平均 $\rightarrow$} & 105.18 & 11.88 & 68.13 & 25.17 & \\
\hline $\begin{array}{l}140 \\
141 \\
142 \\
143 \\
144\end{array}$ & $\begin{array}{c}\text { 3/IX } \\
", \\
" 1 \\
",\end{array}$ & 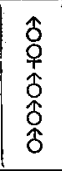 & $\begin{array}{c}27 .{ }^{\circ} \mathrm{C} \\
" \\
" \prime \\
" \prime\end{array}$ & $\begin{array}{r}145.20 \\
75.60 \\
81.60 \\
88.80 \\
132.40\end{array}$ & \begin{tabular}{r|}
15.07 \\
7.07 \\
12.52 \\
10.78
\end{tabular} & \begin{tabular}{|}
115.60 \\
45.60 \\
45.60 \\
73.00 \\
107.60
\end{tabular} & $\left\{\begin{array}{r}14.53 \\
28.93 \\
3.28 \\
14.02\end{array}\right\}$ & 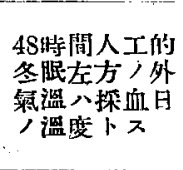 \\
\hline \multicolumn{4}{|c|}{ 以.上 5 例 本均 $\rightarrow$} & $\mid 104.79$ & 11.38 & $77.4 \mathrm{~S}$ & 15.19 & \\
\hline $\begin{array}{l}145 \\
146 \\
147 \\
148\end{array}$ & $\begin{array}{c}\text { 19/1X } \\
\text { ", } \\
\text { ", }\end{array}$ & 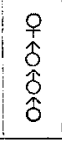 & $\begin{array}{c}23 .{ }^{\circ} \mathrm{C} \\
" \prime \\
"\end{array}$ & $\begin{array}{l}153.60 \\
110.40 \\
110.40 \\
149.60\end{array}$ & $\begin{array}{l}10.65 \\
11.02 \\
11.62 \\
11.13\end{array}$ & \begin{tabular}{|r|}
114.04 \\
76.56 \\
87.00 \\
89.32
\end{tabular} & $\begin{array}{l}28.91 \\
22.82 \\
11.78 \\
49.15\end{array}$ & 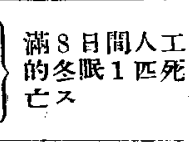 \\
\hline \multicolumn{4}{|c|}{ 以上 4 例平均 $\rightarrow$} & 131.00 & 11.10 & 91.98 & 28.16 & \\
\hline \multicolumn{4}{|c|}{ 以上，總平均 $\rightarrow$} & 112.39 & 11.91 & 78.28 & 22.62 & \\
\hline \multicolumn{4}{|c|}{$\begin{array}{l}\text { 正常基 } 9 \text { 月-10月 }\left(21 .{ }^{\circ} \mathrm{C}\right. \\
\left.\text {-25. }{ }^{\circ} \mathrm{C}\right)=\text { 汵ケル本均 }\end{array}$} & 109.05 & 13.74 & 77.97 & 17.26 & \\
\hline
\end{tabular}

（4）嶉雄各月別諸 窑素含有物侗

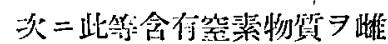
堆别二数察スルト，上記第 2 乃至節 $=$, 冬服中 認メ儿事为出秋ナイガ，符 4

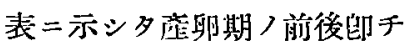
4月灭ビ5月ノ七面八刚性閉二顯 著ナ相拈ガ何儿事ガ物儿。 $\mathrm{R}$. -N. =就テ見レバ 40-50mg\%

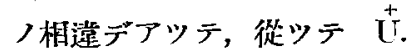
-N. 又八A.-N. э晃テ毛闰 一ノ現㿞 $\rightarrow$ 認メル惑 ル。多保= U.-N.'八雄〉物ノ 2 倍以上习示ス雌モ驸儿。又

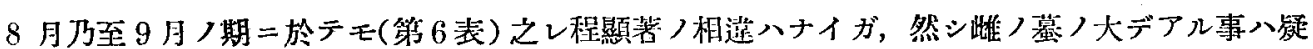

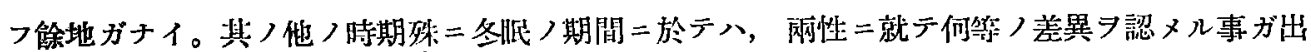

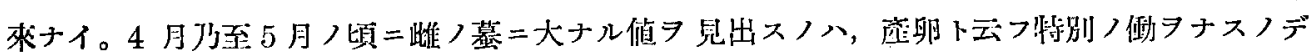

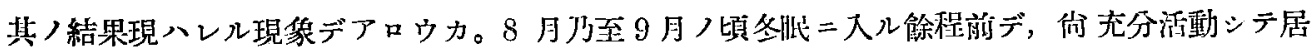

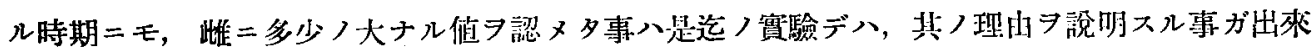
ナイ。

此ノ事實ヨ装二示セバ第 3 圖及ビ第 4 圖ノ通リデアル。

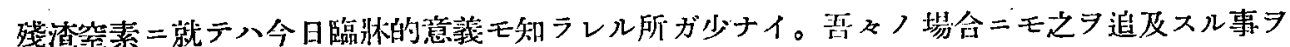

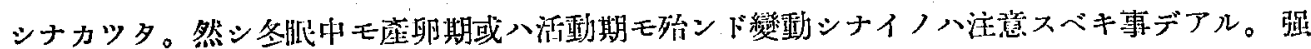

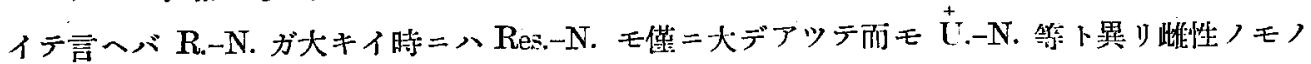
ヨリ雄性ノモノニ却ツテ大ナル傾ガ罗へル。

\section{(5)「アミノ窒素值ト血球數トノ關係}

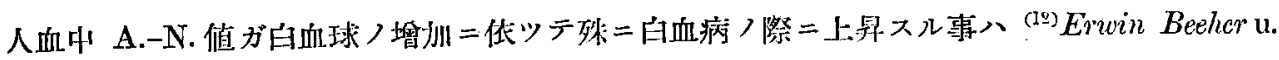

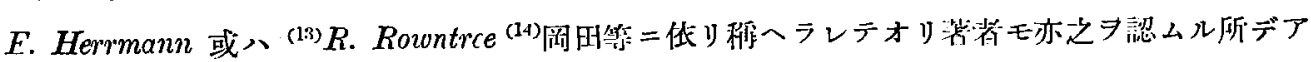

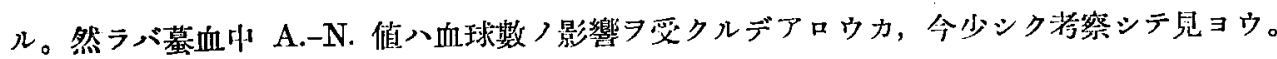

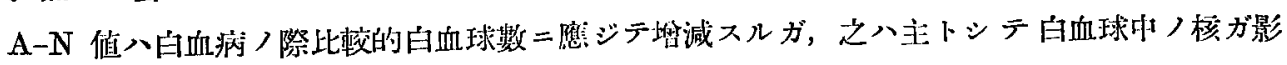

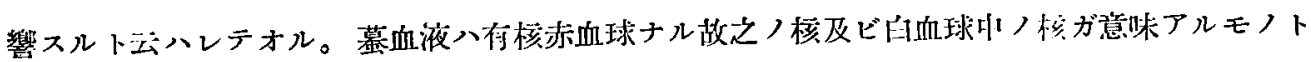




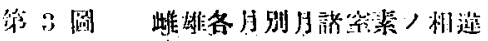

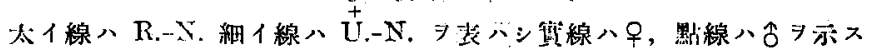

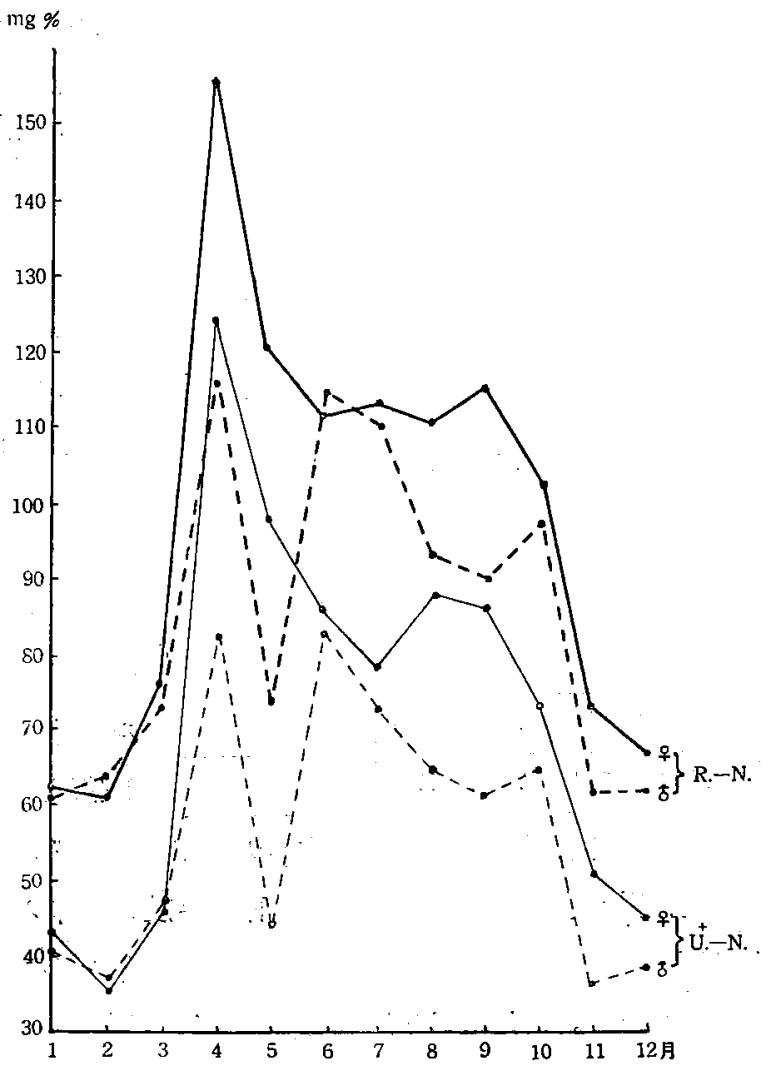

思ハレル。Becher u. Herrmann =低レバ住核赤血球ヨ住スル動物八一般二血中 A. $-\mathrm{N}$. 值八高

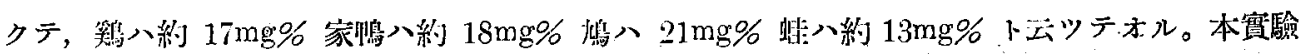

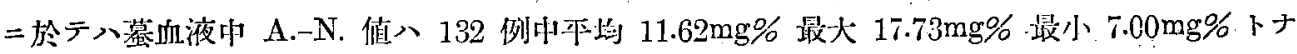

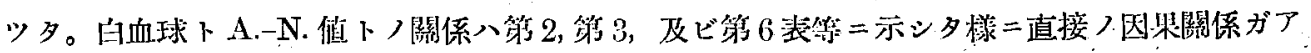
ルトハ思ハレナイカ，上記ノ如ク核フ有スル細胞二富ンダ場合二多量二見出サレル事が明卜ナ．

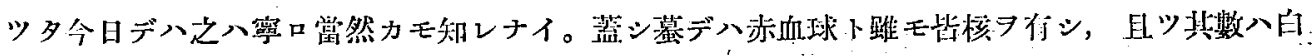

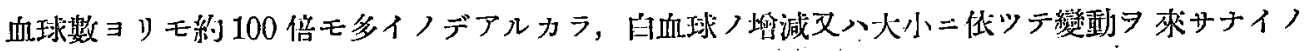

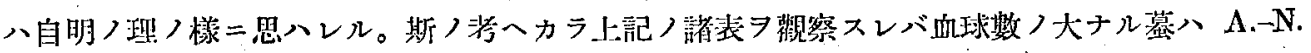

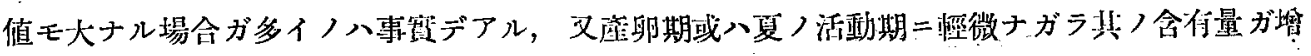

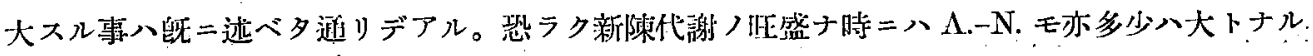

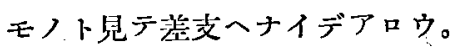

\section{（6）結論}




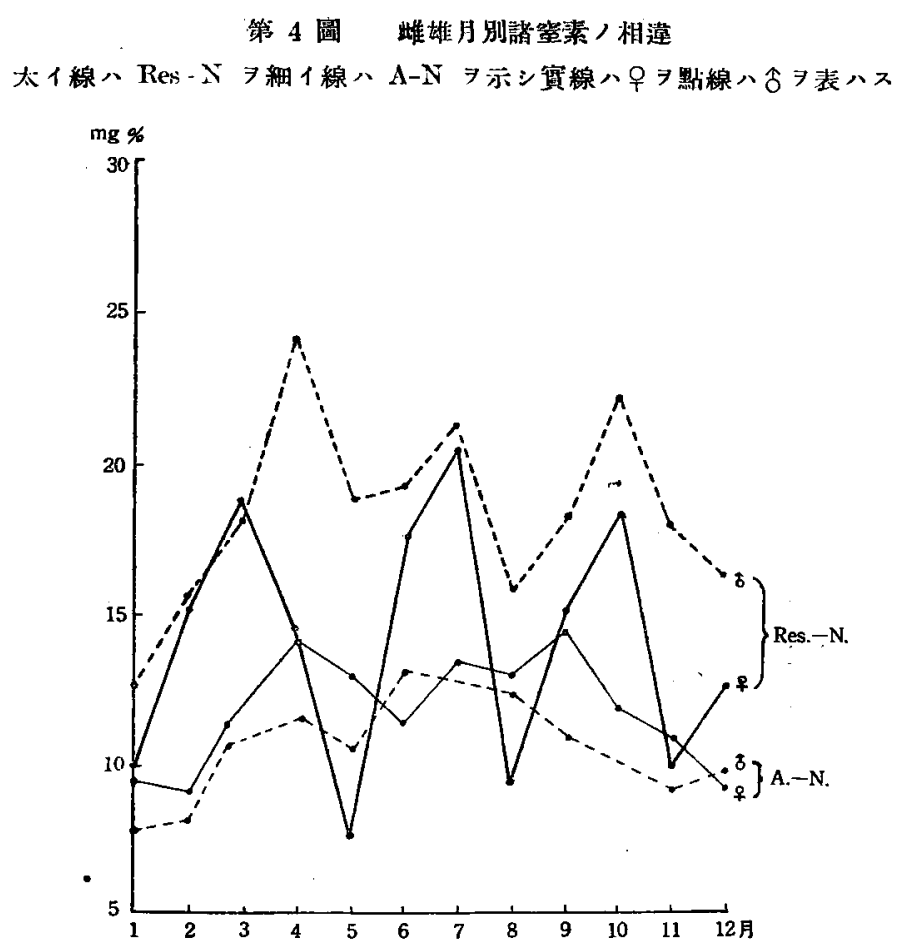

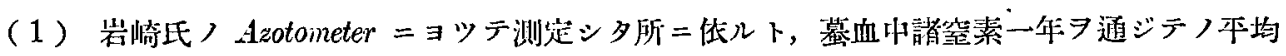
值八 R. $-\mathrm{N} .=85.12 \mathrm{mg} \%, \mathrm{~A} .-\mathrm{N} .=11.62 \mathrm{mg} \%, \stackrel{+}{\mathrm{U}} .-\mathrm{N} .=63.87 \mathrm{mg} \%$, Res. $-\mathrm{N} .=16.58 \mathrm{mg} \%$ トナル。

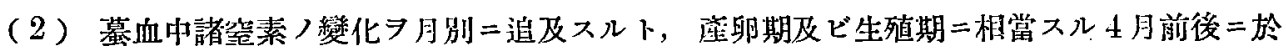

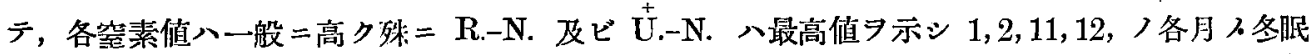
期=於テハ最低值 ヨ示ス。A.-N. 及ビ Res.-N. 值モ共=冬服中八低ク 4 月及夏季二於デ八一般

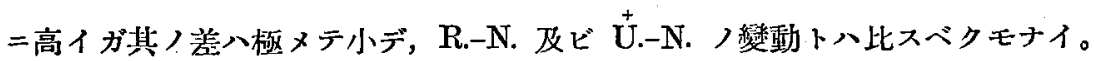

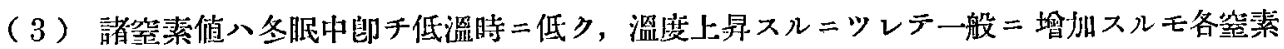

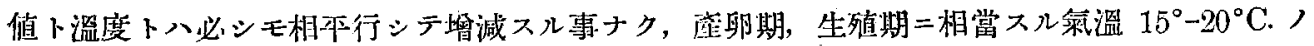
際二最高値习示シ氣溫 $21^{\circ}-35^{\circ} \mathrm{C}$ デハ却ツテ $15^{\circ}-20^{\circ} \mathrm{C}$ ノ時ョリ八低值ニナツテ扂ル。

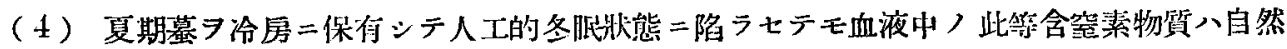

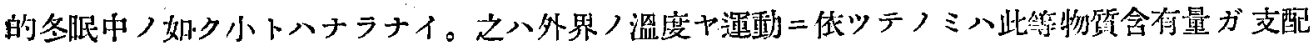

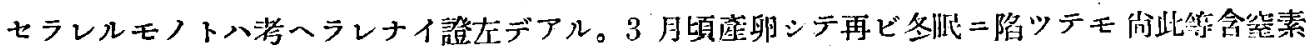
物質量ガ再ビ小トナラナイ事賽ト将へ合スレバ興紫アル事デアル。

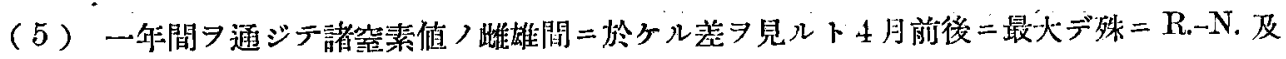

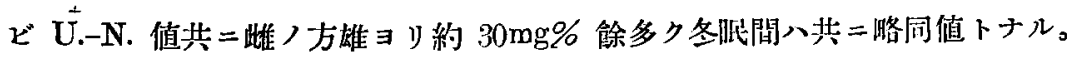

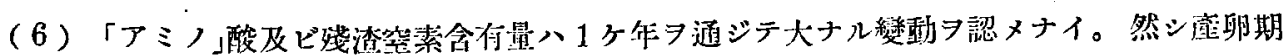


或八夏ノ高溫期二多少八大トナル傾ガアル。殊二殘渣空素八 R.-N. 又八 U๋.-N. ト異り雄性墓 ニ於テ却ツテ大ナル傾アル事ヨ認メタ。

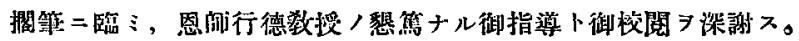

\section{主 用 文 獻}

(1) Ferdmann u. Feinschmidt; Biochem. Z. 248, 87-100 (1932)

（2）矢澤督三郎；成醫會雜

詀 53 卷 4 䟞 488 (昭和 9 -年)

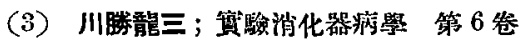

(4) Athanasin; Pflügers Arth ges. Physiol. Bd. 74. S. 561, (5) Arow u. Schwarz; Cpt. rend, des seances de la soc de biol. p. 979, t. 72, No. 12. (6) Langendorff; Arch. für Physiol. S. 280, $1886 . \quad$ (7) 今村;

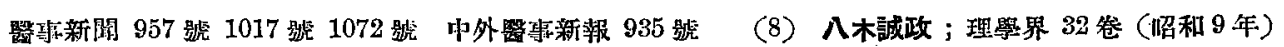

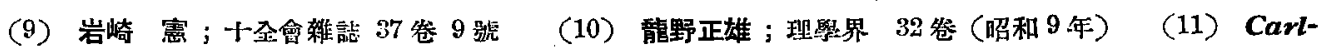
Klieneberger; Die Blutworpholog. der Laboratriumstiere (1927) (12) Erwin Becher u. E. Herrmann; Deutsch. Arch. f. klin. Med. Bd. 171. S. 547-564 (1981) Bd. 173, S. 1-23, (1932) (13) R. Rowntree; Jour. of. Am. Med. Assoc. 63, 1538, (1924)

(14) S. Okada u. Tamura

Hayashi; Journ. of biol chemie 51. 395, (1922)

\section{日 本 噂 學 雜 誌}

\section{並關保雑誌目錄及略名表}

\section{雜 誌 名}

Mitteilungen (aus der) Medizinischen Fakultät der Kaiserlichea Universität zu Tokyo. (東京帝國大學醫學部紀姴)

Mitteilungen (der) Medizinischen Gesellschaft zu Chiba. (千葉醫學會雜誌)

Mitteilungen (der) Medizinischen Gesellschaft zu Nagnya. (愛知整學會雜誌)

Mitteilungen (der) Medicinischen Gesellschaft zu Tokyo. (東京學學會雜誌)

Mitteilungen (der) Medicinischen Sachen. u. Register von den Zeitschriften. (酱事及勧 誌䇣引り

Monatsschrift für Klinische Kinderheilkunde. (隐床小兒科新誌)
略名

Mitt. med. Fak. Tokyo

(Mitt. med. Gesell. Chiba) $=$ Chiba Igk. Z.

(Mitt. med. Gesell. Nagoya) $=$ Aichi Igk. Z.

(Mitt. med. Gesell. Tokyo)=Tokyo Igk. Z.

Iji. Sakuin

Rinshô Shôni. Z. 